\title{
Interferences of Inorganic Arsenic (III \& V) on Growth and Development of Rice (Oryza sativa L.) With Special Emphasis on Root and Coleoptile Growth
}

N.K. Mondal ( $\nabla$ nkmenvbu@gmail.com )

University of Burdwan https://orcid.org/0000-0002-1554-1390

Priyanka Debnath

The University of Burdwan

Debojyoti Mishra

The University of Burdwan

\section{Research Article}

Keywords: Arsenic, Paddy variety, Germination, Morphophysiology, Root Arsenic level, MDA

Posted Date: November 8th, 2021

DOl: https://doi.org/10.21203/rs.3.rs-848767/v1

License: (c) (i) This work is licensed under a Creative Commons Attribution 4.0 International License.

Read Full License 


\title{
Interferences of inorganic arsenic (III \& V) on growth and development of

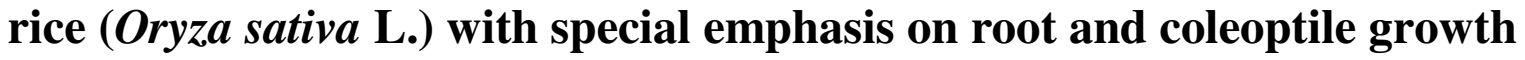

\author{
Naba Kumar Mondal1*, Priyanka Debnath1, Debojyoti Mishra1 \\ ${ }^{1}$ Environmental Chemistry Laboratory, Department of Environmental Science, The University of \\ Burdwan, West Bengal, India; \\ *For correspondence E-mail: nkmenvbu@ gmail.com \\ Cell: +919434545694, Fax: (0342)2634200
}

\begin{abstract}
A short-term phytotoxicity experiment was conducted on four varieties of rice (Oryza sativa L.) under the influence of arsenic (III \& V) to evaluate the impact on root and coleoptiles growth. Four varieties (GB-1, IET-4786, IET-4094, and MTU-1010) of rice were undertaken for this study with different concentrations $(0,5,10,25$ and $50 \mathrm{mg} / \mathrm{L})$ of arsenic (III \& V). Germination along with mean daily germination (MDG), length of root and coleoptile, water holding capacity of root and coleoptiles, fresh and dry weight, arsenic accumulation, MDA and root ion leakage were evaluated. Results highlighted that the percent germination of IET-4094 and MTU-1010 varieties of rice seed over control decreased significantly $(\mathrm{p}<0.05)$ with increasing concentration of both arsenite and arsenate. However, the percent germination of GB-I and IET-4786 dose not affected on the different concentration of both arsenate and arsenite. The root and coleoptile length of all the four varieties showed remarkable decreasing trend over control with increasing concentration of both arsenite and arsenate. However, more pronounced effects were observed for arsenite than arsenate. Similarly, biomass of shoot is less affected than root under different concentration of arsenite and arsenate. The variety IET-4786 and MTU-1010, accumulated lower level of arsenic and variety
\end{abstract}


GB-1 accumulate higher level of MDA level in root under both arsenite and arsenate treatments. Therefore, it can be concluded that the variety IET-4786 and MTU-1010 are the suitable varieties towards phytoremediation of both arsenite and arsenate. Moreover, farmers of arsenic contaminated area are recommended to cultivate IET-4786 and MTU-1010 varieties.

Keywords: Arsenic; Paddy variety; Germination; Morphophysiology; Root Arsenic level; MDA

\section{Introduction}

Arsenic (As) is a metalloid and it is the member of group 15 in modern periodic table. Arsenic is highly toxic due to its chronic and epidemic effects on human health (Li et al. 2019; Ghosh et al. 2016; Lei et al. 2015). Mainly two form of arsenic is available in aquatic medium as arsenite and arsenate (Mondal et al. 2021). Among these two oxidation states, arsenite is more toxic than arsenate (Mitra et al. 2017). Arsenic present in the terrestrial, marine, and fresh water environment in various chemical forms (Shri et al. 2009). The World Health Organization recommended the permissible limit of arsenic in potable water is $10 \mathrm{ppb}$ (Mondal et al. 2014). Literature (Meharg and Hartley-whitaker 2002) highlighted that organic form of arsenic species are less toxic than inorganic species to aquatic plant (Reid et al. 2021), animals and humans, and this has been presumed to be true for terrestrial plants also. Moreover, extensive arsenic rich underground water was used in agricultural lands which leads to enrichment of arsenic in surface soil and subsequently migrated from soil to plants through root system (Afzal et al. 2018). Plants are susceptible to take arsenic in both trivalent (arsenite) and pentavalent (Arsenate) forms, which are again inhibited by different biomolecules of cells (Su et al. 2010; Shri et al. 2009). Hence, it is very difficult to counteract with arsenic and ultimate results are reduction of plant growth and crop productivity (Hasanuzzaman et al. 2015). 
Rice (Oryza satiava L.) is extensively used staple crop throughout the world (Samal et al. 2021; Deng et al. 2018). In India, West Bengal is major rice growing state are affected by arsenic in ground water (Marmiroli et al. 2020; Ganesh et al. 2020; Huhmann et al. 2017). The people of fourteen districts of West Bengal not only drink the arsenic contaminated groundwater but also irrigate their crops (Samal et al. 2021; Marmiroli et al. 2020). Recent literature highlighted the excessive amount of arsenic (>0.01 mg/L) was consuming by the rural people of West Bengal (Samal et al. 2021) and subsequently their daily intake exceed the permissible value of WHO $(0.0021 \mathrm{mg} / \mathrm{kg})$ (Menon et al. 2020).

Irrigation is principally performed in dry seasons for Boro rice cultivation (Rahman et al. 2007). In West Bengal, a large number of shallow tube wells (STWs) and deep tube wells (DTWs) have been installed to irrigate about 1.74 Million hector of crop land which contributes to the food grain production of the country significantly (Mainuddin et al. 2021). Long term irrigation with arsenic contaminated groundwater is likely to increase arsenic concentration in crops (Innamul Huq et al. 2003). Due to such contamination of As in rice, it possess a serious health problems and particularly alarming are baby foods which is mainly prepared from rice; may cause dangerous diseases along with developmental problems in children (Karagas et al. 2016). It is well known that root is the primary organ where any toxicant can encounter first (Huang et al. 2019).

In this study, we hypothesized that different forms of arsenic i.e., arsenate and arsenite will differently acts on different varieties of rice (Oryza satiava L.) especially on root and shoot growth and biomass. Moreover, previous research mostly highlighted on overall toxicity of arsenic on plants. However, very scanty literature are available which mainly focused on the toxicity of both As (III \& V) on root and coleoptile. To test these hypotheses, greenhouse experiment were set up to (1) compare the percentage of germination under different concentrations (control, 5, 10,20, 25 
and $50 \mathrm{mg} / \mathrm{L}$ ) of both arsenate and arsenite; (2) to compare the root length, fresh and dry biomass of four varieties of rice under different concentration of both arsenate and arsenite, (3) to find out the MDA and root ion leakage under different concentration of both arsenate and arsenite, (4) to estimate the arsenic accumulation in roots of four varieties of rice under different concentration of both arsenate and arsenite, (5) to assess the relationship between arsenic uptake and root morphophysiology, MDA, root ion leakage etc. The results of this study would provide a better understanding of the effects of both arsenate and arsenite on root morphophysiology and arsenic accumulation of four varieties of rice.

\section{Materials and methods}

\subsection{Design of the experiment}

Experimental seeds were collected from seed multiplication farm of Burdwan University Burdwan, West Bengal. The greenhouse was set up in the Environmental chemistry laboratory, Burdwan University Burdwan. Variable concentration of arsenic (III/V) salt solution such as (5, 10, 20, 25 and $50 \mathrm{mg} / \mathrm{L})$ ware prepared and same was applied on MTU-1010, IET-4786, IET-4094 and GB-1. Double distilled water was used for control setup. Three separate replications were performed for every treatment with complete randomized design (CRD). The germination of seeds were examined in every 24 hours and morphophysiological and biochemical test were performed after 15 days.

\subsection{Arsenic Solution}

Experimental solution was prepared by following analytical techniques of standard solution preparation (100 mg/L) using double distilled water for both As (III) and As (V). The intermediate solution of different concentrations $(5,10,20,25$ and $50 \mathrm{mg} / \mathrm{L})$ were prepared with proper dilution 
of respective standard solution. Surface sterilization of the experimental seeds were performed by $1 \% \mathrm{NaOCl}$ solution. For germination study, each sterilized petriplate was fitted with a standard size wet filter paper and seeds were taken on this paper. Finally, covered with lid and kept at room temperature.

\subsection{Germination percentage}

Seed germination was recorded daily up to 3 days after the initial day of the experiment. $1.0 \mathrm{~mm}$ specific length of radical was considered as the germination of seed (Kabir et al. 2008). Percentage of germination was evaluated by the following equation (1): Germination percentage $=\frac{\text { Number of germinated seeds }}{\text { Total number of seeds }} x 100$

\subsection{Root and coleoptile length (early seedling growth)}

Length of root and coleoptile was measured with the help of a scale and reading was taken from both treated and controlled plants.

\subsection{Biomass root and shoot}

Root and shoot of both treated and control plants were taken from treatment pot and washed with double distilled water and soaked with tissue paper and fresh weight was recorded by digital balance followed by shade and hot air woven drying until constant weight. Finally dry biomass recorded as $\mathrm{mg} \mathrm{g}^{-1}$.

\subsection{Electrolyte leakage}

The membrane damage was evaluated by the method of Valentoric et al. (2006). About $1.0 \mathrm{~g}$ plant samples (roots) were cut into small pieces and immediately kept in deionized water $(15 \mathrm{~mL})$. The entire plant-deionized water mixture was shaken for $24 \mathrm{~h}$ at room temperature $\left(25-30^{\circ} \mathrm{C}\right)$. The conductivity (EC1) of extracted solution was measured by conductivity meter (HI 8733, Hanna Instruments Inc., Woonsocket, USA). Then the entire samples were autoclaved at $120^{\circ} \mathrm{C}$ for 20 
min and allowed to cool at room temperature and conductivity (EC2) was recorded. Finally, the electrolyte leakage was measured by using the following equation (2):

$$
E L(\%)=\frac{E C 1}{E C 2} x 100
$$

\subsection{Estimation of water holding capacity and dry biomass}

Moisture content (\%) of the study plant materials was determined according to the method suggested by Kaya (1998). This method is based on the principal of "removal of plant water at certain temperature and detection of moisture content according to the resulting weight loss". Percentage of moisture was evaluated by the following equation (Eq. 3):

Water holding capacity $(\%)=\left[\frac{(W 0-W 1)}{W 0}\right] \times 100$

$$
\text { Drybiomass }=W_{0}-W_{1} \text { Where, } \mathrm{W}_{0}=\text { Initial Weight } \mathrm{W}_{1}=\text { Final Weight }
$$

\subsection{Determination of growth parameters}

For estimation of growth parameters, 10 seedlings were randomly selected from each treatment and washed thoroughly with double distilled water and surface water was removed by blotting paper. Then wet weight was recorded by digital balance and in similar way dry weight was recorded after $72 \mathrm{~h}$ of drying the plant samples in hot air over at $70{ }^{\circ} \mathrm{C}$.

\subsection{Determination of MDA content}

Leaf tissue $(0.1 \mathrm{mg})$ was homogenized by adding $10 \mathrm{ml} 0.1 \%(\mathrm{w} / \mathrm{v})$ TCA then Centrifuge the homogenate for $10 \min \left(15,000 \mathrm{x} \mathrm{g}, 4^{\circ} \mathrm{C}\right)$ then Collect supernatant and mix $1 \mathrm{ml}$ of supernatant with $4 \mathrm{ml} 0.5 \%$ TBA diluted in $20 \%$ TCA. The entire mixture was heated at boiling temperature for half an hours. Then the reaction was terminated by cooling the mixture in ice bath. Finally, 
centrifuged at $10,000 \mathrm{x} \mathrm{g}$ for 10 minutes, if the mixture is turbid and absorbance was measured at 532 and $600 \mathrm{~nm}$ (Heath and Packer 1968). The amount of MDA was evaluated by the equation (4):

MDA equivalents $\left(\mathrm{nmol}_{\mathrm{cm}}{ }^{-1}\right)=1000\left[\left(A b s_{523}-A b s_{600}\right) / 155\right]$

\subsection{Total arsenic determination in roots}

For estimation of total As, plants were harvested and roots are separated at the end of the experiment. Then each part of plants was weighted to measure their biomass. The roots were separately dried at $70{ }^{\circ} \mathrm{C}$ until reaching constant weight. The dried samples were separately grinded to powder and $0.1 \mathrm{gm}$ of the grinded sample was digested with concentrated $\mathrm{HNO}_{3}: \mathrm{HClO}_{4} ;(\mathrm{V} / \mathrm{V}$ 9:1) for $2 \mathrm{~h}$. Residues were filtered through Whatman filter paper and diluted to $100 \mathrm{ml}$ with double-distilled water. Concentrations of heavy metals from the digested samples were analyzed using Atomic Absorption Spectrophotometer attached with flow hydride-generation system (GBC Avanta) (Bajpai et al. 2011).

\subsection{Statistical analysis}

The entire experimental data were expressed as mean \pm standard deviation (SD) for three replicate for each experimental point. The statistical difference between treated groups and control groups were determined by ANOVA and DMRT and $\mathrm{p}<0.05$ was considered as significant.

\section{Results and discussion}

\subsection{Germination of paddy variety}


As a preliminary experiment, rice seeds were exposed to five different concentrations of arsenate and arsenite to determine their effects on germination, root and coleoptile length and fresh and dry biomass of root and shoot. From the present study it is clear that the variety IET-4094 is strongly influenced by arsenate than other three varieties (GB-1, 1010 and 4786). However, variety GB-I and IET-4094 showed much lower germination at higher concentration of arsenite (Fig. 1). This is possibly due to higher phytotoxic effect of arsenite (Moulick et al. 2016). On the other hand, none of the variety showed consistent germination with increasing both arsenate and arsenite stress. In lower concentration ( 5 and $10 \mathrm{mg} / \mathrm{L})$ of both arsenate or arsenite, all the tested variety of paddy showed consistent germination ranges from $80-100 \%$ except IET-4074 variety which showed $71.43 \%$ and $57.14 \%$ germination at lower concentration $(5 \mathrm{mg} / \mathrm{L})$ of both arsenate and arsenite, respectively. Metal pollution is assessed through the intensity of seed germination. Therefore, analysis of seedling growth is also important for understanding the impact of heavy metals (Liu et al. 2005). In the present study, germination rate decrease under the influence of arsenic stress. This observation is very much consistent with the earlier reports (Mridha et al. 2021; Mondal et al. 2016; Shri et al. 2009). Rice plant is very much susceptible to arsenic (Upadhyay et al. 2019). Paddy soils and irrigation water were contaminated with high concentration of arsenic is very common in nine districts of West Bengal (Desbarats et al. 2017; Mondal et al. 2011). Rice is the staple food for populations in these countries (Upadhyay et al. 2019). The buildup of As in paddy soils and irrigation water adversely effects rice plant germination and growth and leads to As accumulation in rice grain (Samal et al. 2021; Shri et al. 2009).

\subsection{Mean daily germination (MDG)}

Mean daily germination of four varieties under both arsenate and arsenite treatments are depicted in Figure 2a-h. For variety GB-1, MDG at $24 \mathrm{~h}$ and $48 \mathrm{~h}$ under both arsenate and arsenite showed negative trend (Fig. 2a-b). But IET-4094 variety exhibited positive trend of MDG under arsenate treatment and almost opposite trend under arsenite treatment at both $24 \mathrm{~h}$ and $48 \mathrm{~h}$ (Fig. 2c-d). On

the other hand, MTU-1010 showed strong negative trend of MDG under Arsenate treatment at both $24 \mathrm{~h}$ and $48 \mathrm{~h}$ (Fig. 2e-f). Almost similar negative trend was recorded with arsenite treatment at $48 \mathrm{~h}$ (Fig. 2f). The variety IET-4786 also exhibited negative trend MDG (\%) under both arsenate and arsenite during $24 \mathrm{~h}$ and $48 \mathrm{~h}$ (Fig. $2 \mathrm{~g}$-h). Therefore, from the mean daily germination data it is clear that the variety IET-4094 showed phytotoxic in nature against arsenate. However, root 
arsenic accumulation data revealed that this particular variety (IET-4094) accumulate higher level of As in their root (Table 1). Therefore, this study clearly suggest that the variety IET-4094 has strong power to nullify the strong toxic effect of both arsenite and arsenate salt. This specific variety has some specific inherited trait controlled by multiple genes which my nullify the toxicity of arsenic (Murugaiyan et al. 2019). Present finding showed excellent agreement with the earlier findings as reported by Bhattacharya (2017); Liu et al. (2006); Rahman et al. (2007); Bhattacharya et al. (2010).

\subsection{Variation of root and coleoptile length}

The effect of arsenate and arsenite on the root and coleoptile length of four varieties of rice is presented in Fig. 3a-h. From the Figure 3a-h it is clear that root length of all the tested varieties are strongly influenced by arsenite salts. However, variety MTU-1010 is moderately affected by the arsenate salt solution. Results also demonstrated that the root length of all the tested varieties strongly influenced by arsenate salt solution at lower concentration $(5 \mathrm{mg} / \mathrm{L})$ than the higher concentration. However, at lower concentration $(5 \mathrm{mg} / \mathrm{L})$ of arsenite has much less effect than arsenate salt solution. But at higher concentration $(25 \mathrm{mg} / \mathrm{L})$ the variety IET-4786 showed moderate effects on root length (Fig. 3h). The effect of arsenite solution on root length of four varieties clearly indicates that with increasing concentration, root length gradually decrease. Almost similar level of reduction in root length was reported by Mondal et al. (2015) for mungbean (Vigna radiata (L.) under mercury exposure. However, the intensity of root length reduction by arsenite is much lower than arsenate salt solution. This is possibly due to direct interference of IAA biosynthesis and transportation in roots of rice (Ronzan and Falasea 2018). Previous study (Dey and Mondal 2017) demonstrated that the reduction of root length under the influence of heavy metals is due to hampering of cell division and increase the thickness of cell wall or heavy metals may interact with the phytohormones those are responsible for root development (Soudeh and Zarinkamar 2012). Results also revealed that the variety MTU-1010 is severely affected than other three varieties. On the other hand, the variation of coleoptile length under the influence of both arsenite and arsenate salt solution showed more or less same effects. That means none of the variety showed adverse effect on shoot length under the influence of arsenite or arsenate salt solution (Fig. 3a-h). Abusriuil et al. (2011) reported in their study that plant roots are the main organ where heavy metals directly contact and adsorbed. Influence of heavy metals on the root 
growth is probably due to the fact that roots are the prime organ of plants which directly adsorbed heavy metal from the soil (Abusniuil et al. 2011). Moreover, heavy metals are found to be toxic for root growth because they accumulate on roots and retard cell division and cell elongation. These results agreed with the observation of Angulo-Bejarano et al. (2021) and Chhot and Fulekar (2008).

\subsection{Water holding capacity of root and coleoptiles}

The water holding capacity of different varieties of rice under treatment of both arsenate and arsenite slat solutions are presented in Table S1. From the Table S1 it is clear that all the four tested varieties exhibited an increasing trend of water holding capacity under arsenate salt treatment up to the concentration of $25 \mathrm{mg} / \mathrm{L}$. However, higher concentration $(50 \mathrm{mg} / \mathrm{L})$ of salt solution showed drastic reduction of water holding capacity of all four varieties. On the other hand, arsenite treated plant showed gradual reduction of water holding capacity with increasing concentration except variety IET-4786. Only this variety (IET-4786) showed gradual increment of water holding capacity with increasing concentration of arsenite salt solution up to $20 \mathrm{mg} / \mathrm{L}$. Results also revealed that arsenate treated rice plants holds higher water than arsenite treated plants. This finding is in agreement with the findings of Abbas et al. (2018) for rice seedling contaminated with arsenic.

\subsection{Root and coleoptile fresh and dry biomass}

fresh root biomass of GB-1 gradually decrease with increasing Arsenate concentration up to 10 $\mathrm{mgL}^{-1}$ with respect to control, but after the treatment concentration of $10 \mathrm{mg} / \mathrm{L}$, fresh biomass of root increase with increasing concentration (Fig. 4a-h). Almost similar enhancement of biomass (root and shoot dry weight) was reported by Abusrivil et al. (2011). They reported that mean plant biomass of alfa alfa increased with increasing concentration from 10 to $20 \mathrm{mg} / \mathrm{kg}$ for $\mathrm{Cd}, \mathrm{Cu}$ and Ni. All other varieties also showed more or less same variation with arsenate salt solution (Fig. 4a, c, e and g). Almost similar pattern of root biomass reduction was recorded for arsenate salt solution also (Fig. b, d, f and h). On the other hand, shoot biomass equally affected by both arsenate and arsenite salt solution. From the dry biomass of root and shoot, it also clear that root biomass per plant strongly influenced by both arsenate and arsenite salt solution. However, shoot dry biomass per plant comparatively less influenced by arsenate and arsenite salt solution with respect to 
control. Similar variation of biomass under the influence of arsenic salt was reported by Ronzan et al. (2018) and Zanella et al. (2016).

\subsection{Arsenic in root}

Arsenic accumulation in roots of four varieties of paddy has been evaluated and the results are depicted in Table 1. From the Table 1 it is clear that different variety of paddy exhibited different accumulation pattern. However, all varieties showed a liner relationship with the concentration of arsenic (Table 1). That means arsenic accumulation is concentration dependent (Yao et al. 2021; Zhao and Wang, 2020). Results also revealed that arsenate treated rice varieties showed higher accumulation of total arsenic in root than arsenite treatments in all varieties except variety GB-1. One-way ANOVA analysis also indicated a statistical differences among different treatments of four varieties of rice for both arsenite and arsenate (Table 1). This is perhaps due to higher translocation of arsenate from root to shoot (Awasthi et al. 2017). Present study results is in agreement with the recent study reported by Ronzan et al. (2018). However, previous research of arsenic treatment on paddy reported that the average arsenic bioaccumulation in different parts of rice plants root $>$ stem $>$ leaf $>$ grain (Das et al. 2013). Among the four tested varieties, root accumulation pattern was recorded as IET-4094> MTU-1010 > IET-4786 > GB-1. The higher level of arsenic accumulation by IET-4094 variety was also reported by Bhattacharya (2017). At lower concentration ( 5 and $10 \mathrm{mg} / \mathrm{l}$ ), minimum level of arsenic (III) was accumulated in variety GB-1 and higher level of accumulation was observed in variety MTU-1010 (Table 1). Almost similar accumulation pattern of arsenate was observed for variety GB-1. Similarly, higher level of root arsenic was recorded with arsenate treatment for variety IET-4094. On the other hand, variety GB-1 and IET-4786 showed lower root arsenic accumulation with treatment of arsenate and arsenite at intermediate concentration $\left(20\right.$ and $\left.25 \mathrm{mgL}^{-1}\right)$. At higher concentration (50 mg/l), IET4786 and MTU-1010 showed higher root arsenic accumulation for both arsenate and arsenite treatment, respectively.

\subsection{MDA content and root ion leakage}

Malonaldehyde formation depends on the level of peroxidation of membrane lipid (Chandrakar et al. 2018). Present results revealed that arsenic induced MDA level increased with increasing arsenic level in both arsenate and arsenite treatments (Table 2). However, the amount of MDA 
under arsenate treatment was low in MTU-1010 and both arsenite and arsenate treatment in IET4786. One-way ANOVA analysis revealed statistical significant among different treatments for both arsenite and arsenate (Table 2). The enhancement of MDA level under both arsenate and arsenite treatments revealed the extensive membrane damage due to generation of ROS under the influence of peroxidation of polyunsaturated fatty acids (Conrad et al. 2018). On the other hand, arsenic mediated membrane damage again confirm from the data obtained from root ion leakage (Table 3). The results of root ion leakage demonstrated that the gradual increment of electrolyte leakage with increase of both arsenate and arsenite treatment concentration. However, it is interesting to note that in both MDA level and root ion leakage, arsenate treated plants showed higher value than arsenite and one-way ANOVA analysis suggested that it is statistically significant (Table 2 and 3). This is perhaps due to the toxicity of arsenate is more than arsenite. Present finding is in agreement with the earlier study as reported by Mondal (2017) and Singh et al. (2012) for fluoride toxicity in rice and for aluminium in chickpea (Cicer arietinum L.)

\subsection{Correlation study}

Correlation study revealed that arsenic level in roots negatively related with percentage germination $(\mathrm{r}=$ $0.609, \mathrm{p}<0.275)$. Similarly, arsenic level in root negatively correlated with root fresh weight $(r=-0.928$, $\mathrm{p}<0.023)$, root dry weight $(\mathrm{r}=-0.963, \mathrm{p}<0.008)$ and mean daily germination $(\mathrm{r}=-0.962, \mathrm{p}<0.009)$ for rice variety GB-I under the Arsenate stress (Table S3). But arsenite showed less toxicity only root fresh weight and shoot fresh weight are negatively correlated as $r=-0.979(\mathrm{p}<0.004)$ and $-0.845(\mathrm{p}<0.072)$, respectively (Table S4). The root arsenic level only showed negative impact on both shoot fresh $(\mathrm{r}=$ $0.202)$ and dry weight $(r=-0.138)$ for the variety IET-4094 with arsenate treatment. However MDA level exhibited significant by $(\mathrm{p}<0.0005)$ positive relationship $(\mathrm{r}=+0.976)$ with arsenic level in root (Table S5). But, arsenite showed negative correlation on both root fresh $(\mathrm{r}=-0.856)$ and dry weight $(\mathrm{r}=-0.912)$ (TableS6). The variety IET-4786 also showed similar impact on shoot fresh and dry biomass under Arsenate treatment (Table S7). The results also revealed that root ion leakage significantly related with root arsenic level $(\mathrm{r}=+0.987, \mathrm{p}<0.002)$ and malonaldelyde level $(\mathrm{r}=+0.997, \mathrm{p}<0.0001)$. However, this particular variety exhibited extremely sensitive withes $(V)$ salt on percentage of germination $(r=-0.810, p<0.097)$, and mean daily germination at $24 \mathrm{~h}(\mathrm{r}=-0.882, \mathrm{p}<0.048)$ and $48 \mathrm{~h}(\mathrm{r}=-0.810, \mathrm{p}<0.097)$ with root arsenic level (Table S8). On the other hand, MTU-1010 is strongly affected on fresh biomass of both root $(\mathrm{r}=$ $0.928, \mathrm{p}<0.023)$ shoot $(\mathrm{r}=-0.902, \mathrm{p}<0.036)($ Table S9). But root arsenic level and malonaldelyde level significantly correlated with root ion leakage under Arsenate treatment. However, arsenite treatment has significant negative relation with root $(r=-0.963, p<0.009)$ and shoot dry $(r=-0.854, p<0.065)$ dry 
weight (Table S10). Similar negative impact of arsenic was recorded by Mandich et al. (2013) for two winter wheat varieties.

\section{Conclusion}

In conclusion, present finding demonstrate that both arsenate and arsenite have negative impact on rice (O. sativa L.) root system which is again confirmed from MDA and root ion leakage data. The accumulation of arsenic in rice root of four varieties is as follows: MTU-1010 > IET-4786 > IET$4090>$ GB-1. These results also supported with root architecture changes which may again negatively influence on plant survival in intensely polluted rice cultivated soil. Moreover, Toxic elements migrated through root system present a risk not only to plants but also to the consumers at the higher trophic levels. Therefore, it is strongly recommended that irrigation water should be free from arsenic and use of arsenic tolerant rice varieties etc. should be judicially chosen during raising of rice seedling in the arsenic affected area of West Bengal. Moreover, tolerance to both arsenate and arsenite at germination and seedling stages might be considered as a prime selection criterion for arsenic tolerance varieties. On the other hand, accumulation of such higher level of arsenic can cause a tremendous threat to the grazing animals and the inhabitants of that area are directly affected by contaminated milk products and meat. Therefore, present outcome focused towards food safety with potential impact of both plants and animal health.

\section{Acknowledgements}

All authors extend their sincere thanks to all faculty members, research scholars and M.Sc. students of the Department of Environmental Science, The University of Burdwan, for their both academic and moral support for completion of the present research work.

\section{Author contributions}

Naba Kumar MMondal: The experimental design, statistical calculation and manuscript drafting, Priyanka Debnath and Debojyoti Mishra: Execution of entire experiment, typing and editing the MS. Moreover, all authors have read and approved the present manuscript. 


\section{Funding}

This research work was financially supported by the funding agency DST, Govt. of India under vide Memo No: CRG/2019/004506 dated 14.01.2020. The fund was used for purchase of instruments and scholar's fellowship.

\section{Data Availability}

The datasets generated during and/or analysed during the current study are available from the corresponding author on reasonable request.

\section{Declarations}

Conflicts of Interests The authors have no conflicts of interest to declare that are relevant to the content of this article.

Ethics Approval Not applicable.

Consent to Participate Not applicable.

Consent for Publication Not applicable.

\section{References}

Abbas G, Murtaza B, Bibi I, Shahid M, Niazi NK, Khan MI, Amjad M, Hussain M, Natasha (2018) 
Arsenic Uptake, Toxicity, Detoxification, and Speciation in Plants: Physiological, Biochemical, and Molecular Aspects. Int J Environ Res Public Health. 15(1):

59. doi: 10.3390/ijerph15010059

Adeloju SB, Khan S, Patti AF (2021) Arsenic Contamination of Groundwater and Its Implications for Drinking Water Quality and Human Health in Under-Developed Countries and Remote Communities-A Review. Appl Sci 11:1926. https://doi.org/10.3390/app11041926

Afzal B, Hussain I, Farooqi A (2018) Arsenic in paddy soils and potential health risk. Environmental Pollution of Paddy Soils. Springer, Cham, pp. 151-163. https://doi.org/10.1007/978-3-319-93671-0_10

Angulo-Bejarano, P.I.; Puente-Rivera, J.; Cruz-Ortega, R. Metal and Metalloid Toxicity in Plants: An Overview on Molecular Aspects. Plants 2021, 10, 635. https://doi.org/10.3390/plants 10040635

Awasthi S, Chauhan R, Srivastava S, Tripathi RD (2017) The journey of arsenic from soil to grain in rice. Frontiers Plant Sci 8:1007. doi.org/10.3389/fpls.2017.01007

Bajpai R, Mishra K G, Mohabe S, Marg R, Upreti D, Nayaka S (2011) Determination of atmospheric heavy metals using two lichen species in Katni and Rewa cities. J Environ Biol 32:195-199. PMID: 21882655.

Bhattacharya P (2017) Assessment of arsenic accumulation by different varieties of rice (Oryza sativa L.) irrigated with arsenic-contaminated groundwater in West Bengal (India). Environ Pollut Protect 2:92-99. DOI: 10.22606/epp.2017.23002

Bhattacharya P, Samal AC, Majumdar J, Santra SC (2010) Accumulation of arsenic and its distribution in rice plant (Oryza sativa L.) in Gabgetuc West Bengal, India. Paddy Water Environ 8:63-70. doi.org/10.1007/s10333-009-0180-z

Chandrakar V, Dubey A, Keshavkant S (2018) Modulation of arsenic-induced oxidative stressandprotein metabolism by diphenyleneiodonium,24-epibrassinolide and proline in Glycine Acta Botanica Croaticaax L. Acta Bot Croat 77:51-61. DOI: 10.2478/botcro2018-0004

Conrad M, Kagan VE, Bayir H, Pagnussat GC, Head B, Traber MG, Stockwell 
BR (2018) Regulation of lipid peroxidation and ferroptosis in diverse species. Genes Develop 32:602-619. doi: 10.1101/gad.314674.118.

Das I, Ghosh K, Das DK, Sanyal SK (2013) Assessment of arsenic toxicity in rice plants in areas of West Bengal. Chem. Speciation Bioavailability 25(3):201-208. doi.org/10.3184/095422913X13785717162124

Deng F, Yamini N, Ma JF, Lee SK (2018) Engineering rice with lower grain arsenic. Plant Biotechnol 16:1691-1699. doi.org/10.1111/pbi.12905

Desbarats AJ, Pal T, Mukherjee PK, Beckie RD (2017) Geochemical evolution of groundwater flowing through arsenic source sediments in an aquifer system of West Bengal, India. Water Resour Res 53 (11):8715-8735. https://doi.org/10.1002/2017WR020863

Ganesh V, Yadav A, Seshan K (2020) Silent, slow-onset disaster: weak state response to arsenic poisoning: case studies in Assam and West Bengal. In: Andharia, J. (Ed.), Disaster Studies. Springer, Singapore, pp. 337-356. DOI:10.1007/978-981-32-9339-7_16

Ghosh SB, Chakraborty D, Mondal (2016) Effect of Arsenic and Manganese Exposure on Intellectual Function of Children in Arsenic Stress Area of Purbasthali, Burdwan, West Bengal. Expo Health 9:1-11. doi.org/10.1007/s12403-016-0216-8

Hasanuzzaman M, Nahar K, Hakeem KR, Öztürk M, Fujita M (2015) Chapter 16 - Arsenic Toxicity in Plants and Possible Remediation. Soil Remed Plants 433-501 doi.org/10.1016/B978-0-12-799937-1.00016-4

Heath RL, Packer L (1968) Photoperoxidation in isolated chloroplasts. I. Kinetics and stoichiometry of fatty acid peroxidation. Arch. Biochem Biophys 125:189-198. doi.org/10.1016/0003-9861(68)90654-1

Huang B, Guo Z, Xiao X, Zeng P, Peng C (2019) Changes in chemical fractions and ecologicalrisk prediction of heavy metalsin estuarine sediments of Chunfeng Lake estuary. China Mar Pollut Bull 138:575-583. doi: 10.1016/j.marpolbul.2018.12.015. 
Huang LU, Li WC, Tam NFY, Ye Z (2019) Effects of root morphology and anatomy on cadmium uptake and translocation in rice (Oryza sativa L.). J Environ Sci 95:296-306. DOI: 10.1016/j.jes.2018.04.005

Karagas MR, Punshon T, Sayarath V, Jackson BP, Folt CL, Cottingham KL

(2016) Association of rice and rice product consumption with arsenic exposure early in life. JAMA Pediatr 170:609-616. DOI: 10.1001/jamapediatrics.2016.0120.

Kaya N (1998) Biyokimya Uygulama Kılavuzu. Ege University Press, Izmir.

Liu WJ, Zhu YG, Hu Y, Williams PN, Gault AG, Meharg AA (2006) Arsenic sequestration in iron plaque, its accumulation and speciation in mature rice plants (Oryza sative L.). Environ Sci Technol 40:5730-5736. doi.org/10.1021/es060800v

Liu WJ, Zhu YG, Smith FA (2005) Effects of iron and manganese plaques on arsenic

Uptake by Rice seedlings (Oryza sativa L.) grown in solution culture supplied with arsenate and arsenite. Plant Soil 277:127-138. doi.org/10.1007/s11104-005-6453-4

Li B, Zhou S, Wei D, Long J, Peng L, Tie B, Williams PN, Lei M (2019)

Mitigating arsenic accumulation in rice (Oryza sativa L.) from typicalarsenic contaminated paddy soil of southern China using nanostructured $\alpha-\mathrm{MnO}_{2}$ : Pot experiment and field application. Sci Total Environ 650:546-556. doi.org/10.1016/j.scitotenv.2018.08.436

Liu C, Yu HY, Liu C, Li F, Xu X, Wang Q (2015) Arsenic availability in rice from a miningarea: is amorphous iron oxide-bound arsenic a source or sink? Environ Pollut 199:95-101. doi: 10.1016/j.envpol.2015.01.025.

Mahdieh S, Ghaderian SM, Karimi N (2013) Effect of arsenic on germination, photosynthesis and growth parameters of two winter wheat varieties in Iran. J Plant Nutr 36:651-664. doi.org/10.1080/01904167.2012.754036

Mahdieh S, Ghaderian SM, Karimi N (2013) Effect of arsenic on germination,

photosynthesis and growth parameters of two winter wheat varieties in Gran. J Plant Nutr 36:651-664. doi.org/10.1080/01904167.2012.754036

Mandal S, Karmakar M, Mondal S (2018) Performance of few new paddy different, paddy varieties at lateritic soil of West Bengal, India. Int J Sci Environ Technol 7(5):1592-1596 
Mainuddin M, Alam MM, Maniruzzaman M, Kabir MJ, Mojid MA, Hasan MM, et al. (2021)

Yield, profitability, and prospects of irrigated Boro rice cultivation in the North-West region of Bangladesh. PLoS ONE 16(4): e0250897. https:// doi.org/10.1371/journal.pone.0250897

Marmiroli M (2020) A brief status report on arsenic in edible vegetable species. In: Srivastava, S. (Ed.), Arsenic in Drinking Water and Food. Springer, Singapore, pp. 325-331. ISBN: 978-981-13-8587-2

Mawia AM, Hui S, Zhou L, Li H, Tabassum J, Lai C, Wang J, Shao G, Wei X, Tang S, Luo J, Hu S, Hu P (2021) Inorganic arsenic toxicity and alleviation strategies in rice. J Hazard Mater 408:124751 https://doi.org/10.1016/i.jhazmat.2020.124751

Meharg AA (1994) Integrated tolerance mechanisms-constitutive and adaptive plant-responses to elevated metal concentrations in the environment. Plant Cell Environ 17:989-993. doi.org/10.1111/j.1365-3040.1994.tb02032.x

Menon M, Sarkar B, Hufton J, Reynolds C, Rein SV, Young S (2020) Do arsenic levels in rice pose a health risk to the UK population? Ecotoxicol Environ Safety 197:110601 https://doi.org/10.1016/j.ecoenv.2020.110601

Mitra A, Chatterjee S, Moogouei R, Gupta DK (2017) Arsenic accumulation in rice and probable mitigation approaches: A review. Agronomy 7:67. Doi: 10.3390/agronomy7040067

Mondal NK, Chakraborty D, Roy P, Das C, Bhaumik R, Pal KC, Medda S, Datta JK (2014) Correlation between arsenic intoxication and cognitive ability of primary school children of West Bengal. Asian Pac J Trop Dis 4(Suppl 2): S850. doi: 10.1016/S22221808(14)60743-X

Mondal NK, Sen K, Banerjee A, Datta JK (2016) Toxicity of Arsenate and Arsenite on morphological traits and pigments of Gram seed (Cicer arietinum) during germination and early seedling growth. Commun Plant Sci 6:1-6

Mondal NK, Roy P, Das B, Datta JK (2011) Chronic arsenic toxicity and it's relation 
with nutritional status: a case study in Purabasthali-II, Burdwan, West Bengal, India. Int J Environ Sci 2:1103-1118.

Mondal NK, Debnath P, Sen K, Mondal A, Mishra D, Mondal A (2021) Chicken litter: a potential source of arsenic in agricultural soil and its contamination in Cajanus cajan. Int J Environ Technol https://doi.org/10.1007/s13762-021-03548-z

Mondal NK (2017) Effect of fluoride on photosynthesis, growth and accumulation of four widely cultivated rice (Oryza sativa L.) varieties in India. 144:36-44. doi:

10.1016/j.ecoenv.2017.06.009

Mondal NK, Das C, Datta JK (2015) Effect of mercury on seedling growth, nodulation and ultrastructural deformation of Vigna radiata (L) Wilczek. Environ. Monitor. Assess. 187: 241. DOI 10.1007/s10661-015-4484-8

Moulick D, Ghosh D, Santra CS (2016) Evaluation of effectiveness of seed priming with selenium in rice during germination under arsenic stress. Plant Physiol. Biochem. 109: 571-578. https://doi.org/10.1016/j.plaphy.2016.11.004.

Mridha D, Paul I, De A, Ray I, Das A, Joardar M, Chowdhury NR, Bhadoria PBS, Roychowdhury T (2021) Rice seed (IR64) priming with potassium humate for improvement of seed germination, seedling growth and antioxidant defense system under arsenic stress. Ecotoxicol Environ Safety 219:112313. https://doi.org/10.1016/j.ecoenv.2021.112313

Murugaiyan, V., Ali, J., Mahender, A. Aslam UM, Jewel ZA, Pang U, Marfori-Nazarea CM, Wu LB, Frei M, Li Z (2019) Mapping of genomic regions associated with arsenic toxicity stress in a backcross breeding populations of rice (Oryza sativa L.). Rice 12:61. https://doi.org/10.1186/s12284-019-0321-y

Reid MC, Asta MP, Falk L, Maguffin SC, Pham VHC, Le HA, Latmani RB-

L, Vo PL (2021) Associations between inorganic arsenic in rice and groundwater arsenic in the Mekong Delta. Chemosphere 265:129092. doi.org/10.1016/j.chemosphere.2020.129092

Ronzan M, Falasca G (2018) Cadmium and arsenic affect root development in Oriza sativa

L. regularly interacting with auxin. Environ Exp Bot 151:64-75

doi.org/10.1016/j.envexpbot.2018.04.008

Rahman MA, Hasegawa H, Rahman MM, Islam MN, Miah MAH, Tasmin A 
(2007) Effect of arsenic on photosynthesis, growth and yield of five widly cultivated rice (Oryza sativa L.) varieties in Bangladesh. Chemosphere 67:1072-1079. DOI: 10.1016/j.chemosphere.2006.11.061

Ronzana M, Piacentinia D, Fattorinia L, Della RF, Eiche E, Riemann M, Altamura M

M, Falasca G (2018) Cadmium and arsenic affect root development in Oryza sativa L. negatively interacting with auxin. Environ Exp Bot 151:64-75. DOI: 10.1016/j.envexpbot.2018.04.008

Samal AC, Bhattacharya P, Biswas P, Maity JP, Bundschuh

J, Santra SC (2021) Variety-specific arsenic accumulation in 44 different rice cultivars ( $O$. sativa L.) and human health risks due to co-exposure of arsenic-contaminated rice and drinking water. J Hazard Mater 407:124804. doi.org/10.1016/j.jhazmat.2020.124804

Shri M, Komar S, Chakrabarty D, Trivedi PK, Mallick S, Misra P, Shukh D, Mirshra

S, Srivastava S, Tripathi RD, Tuli R (2000) Effect of arsenic on growth, oxidative stress, and antioxidant system in rice seedlings. Ecotoxicol Environ Saf 72:1102-1110. doi: 10.1016/j.ecoenv.2008.09.022.

Singh S, Verma A, Dubey VK (2012) Effectivity of anti-oxidative enzymatic systemon diminishing the oxidative stress induced by aluminium in chickpea (Cicer arietinum L.) seedlings. Braz J Plant Physiol 24:47-54. DOI: 10.1590/S1677-04202012000100007

Sandhi A, Greger M, Landberg T, Jacks G, Bhattacharya P (2017) Arsenic concentrations in local aromatic and high-yielding hybrid rice cultivars and the potentials health risk: a study in an arsenic hotspot. Environ Monit Assess 189(4):184-189. doi: 10.1007/s10661-017-5889-3.

Soudeh F, Zarinkamar F (2012) Morphological and anatomical responses of Mafricaria Chamomilla plants to cadmium and calcium. Adv Environ Biol 6:1603-1609.

Su YH, McGrath SP, Zhao FJ (2010) Rice is more efficient in arsenite uptake and translocation than wheat and barley. Plant Soil 328:27-34

Upadhyay MK, Majumdar A, Suresh Kumar J and Srivastava S (2020) Arsenic in Rice AgroEcosystem: Solutions for Safe and Sustainable Rice Production. Front. Sustain. Food Syst. 4:53. doi: $10.3389 /$ fsufs. 2020.00053

Upadhyay MK, Majumdar A, Barla A, Bose S, Srivastava S (2019) 
An assessment of arsenic hazard in groundwater-soil-rice system in two villages of Nadia district, West Bengal, India. Environ. Geochem Health https://doi.org/10.1007/s10653-019-00289-4

Valentoric P, Luxova M, Kolarovic L, Gasparikov O (2006) Effect of osmotic stress on

compatiblesolutes content, membrane stability and water relations in two maize cultivars. Plant Cell Environ 52:186-91. DOI: 10.17221/3364-PSE

Yao B-M, Chen P, Zhang H-M, Sun G-X (2021) A predictive model for arsenic accumulation in rice grains based on bioavailable arsenic and soil characteristics. J Hazard Mater 412: 125131. https://doi.org/10.1016/j.jhazmat.2021.125131.

Zhao F-J, Wang P (2020) Arsenic and cadmium accumulation in rice and mitigation strategies.

Plant Soil 446:1-21. doi.org/10.1007/s11104-019-04374-6

Zanella L, Fattorini L, Brunetti P, Roccotiello E, Cornara L, D'Angeli S, Della RF, Cardarelli M, Barbieri M, Sanità di TL, Degola F, Lindberg S, Altamura MM, Falasca G (2016) Overexpression of AtPCS1 in tobacco increases arsenic and arsenic plus cadmium accumulation and detoxification. Planta 243:605-622. DOI 10.1007/s00425015-2428-8 
Figures

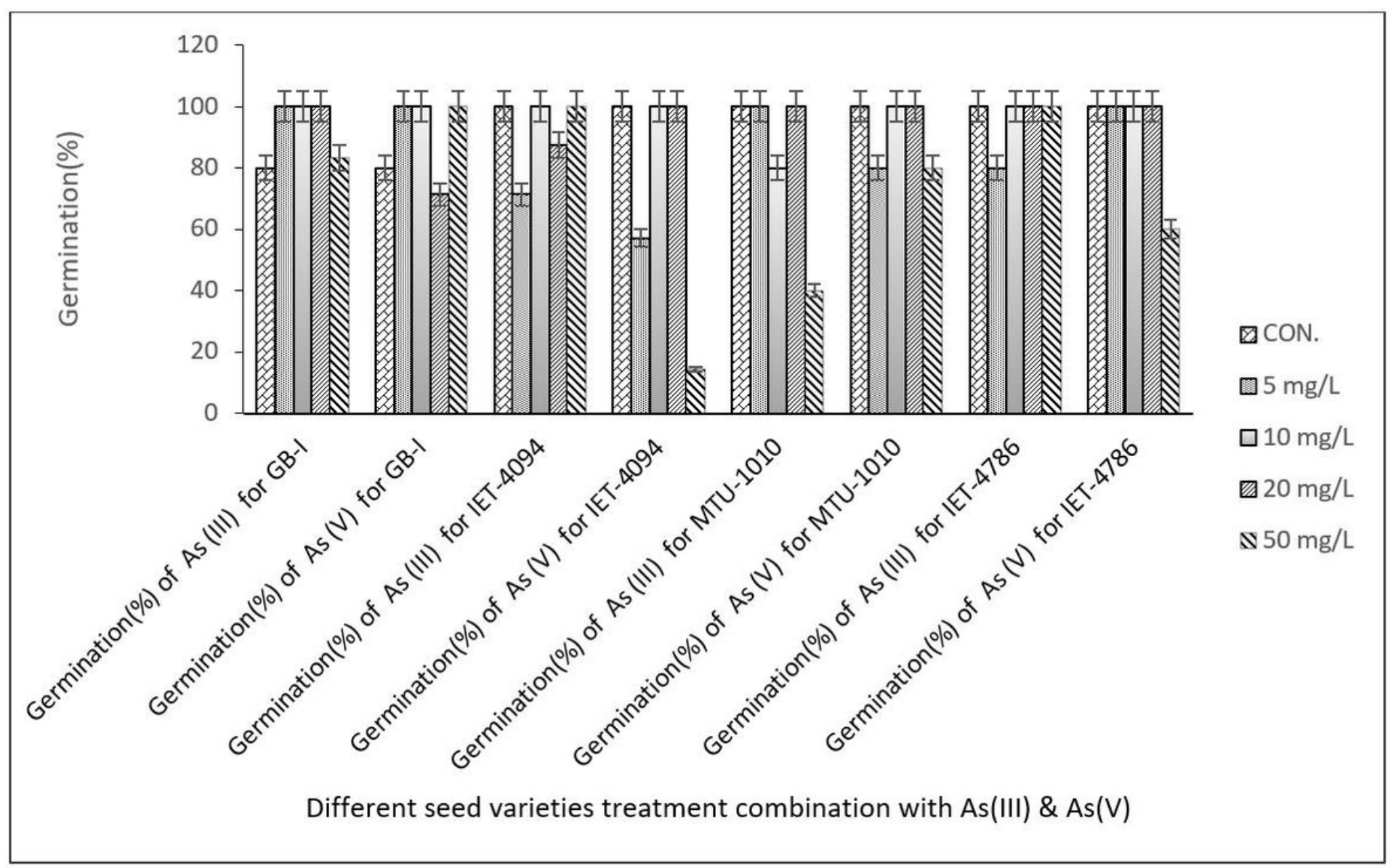

Figure 1

Percentage of germination of four tested varieties of rice underdifferent concentration of both As $3+$ and As5+ salt solution treatment 


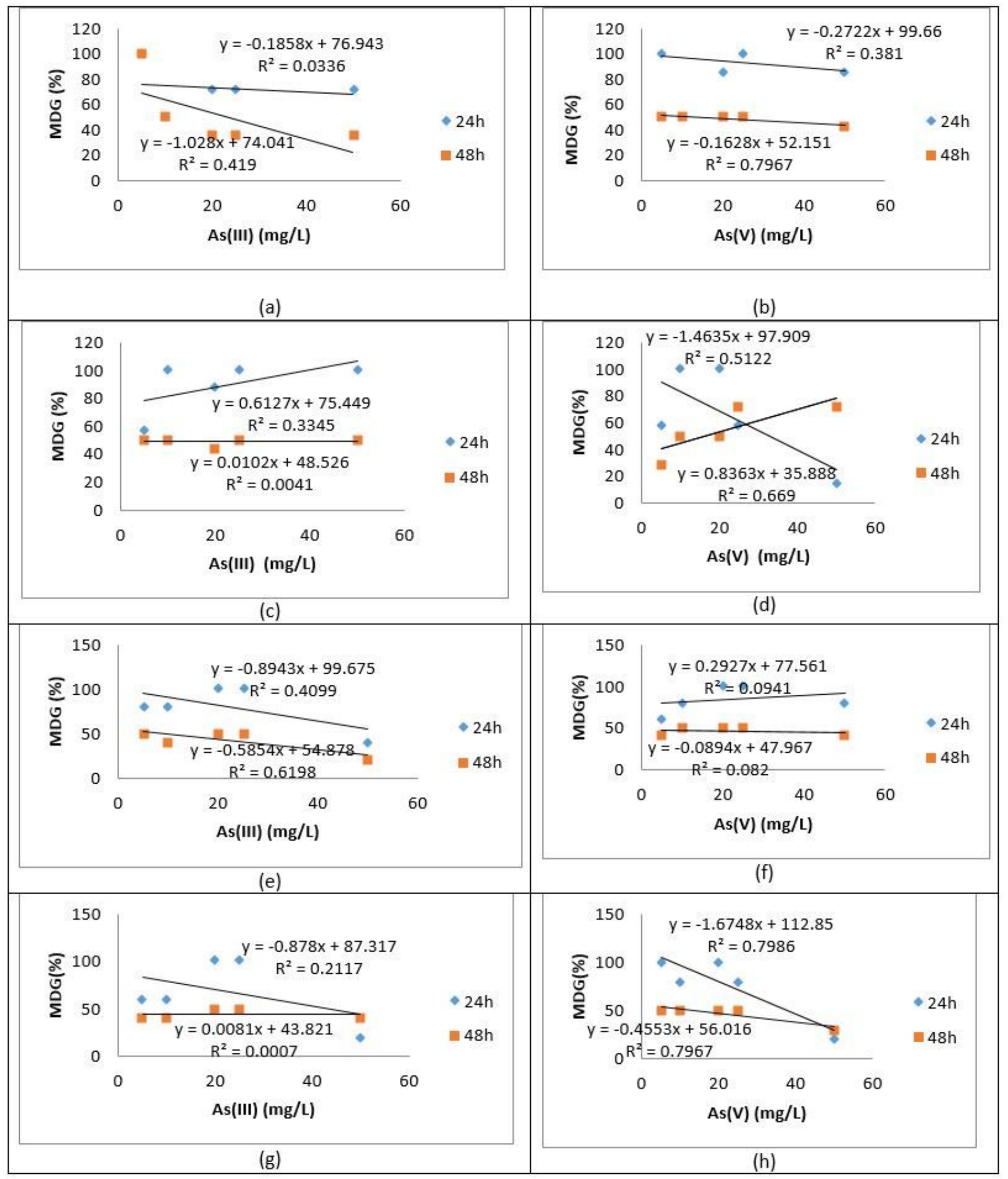

\section{Figure 2}

Mean daily germination (MDG) of various rice varieties : (a )GB-1 at $24 \mathrm{~h}$ and $48 \mathrm{~h}$ for As3+; (b) GB-1 at $24 \mathrm{~h}$ and $48 \mathrm{~h}$ for As5+ ; (c) IET-4094 at $24 \mathrm{~h}$ and $48 \mathrm{~h}$ for As3+; (d) IET-4094 at $24 \mathrm{~h}$ and $48 \mathrm{~h}$ for As5+; (e) MTU-1010 at $24 \mathrm{~h}$ and $48 \mathrm{~h}$ for As3+; (f) MTU-1010 at $24 \mathrm{~h}$ and $48 \mathrm{~h}$ for As5+; (g) IET-4786 at $24 \mathrm{~h}$ and 48 $\mathrm{h}$ for As3+; (h) IET-4786 at $24 \mathrm{~h}$ and $48 \mathrm{~h}$ for As5+. 

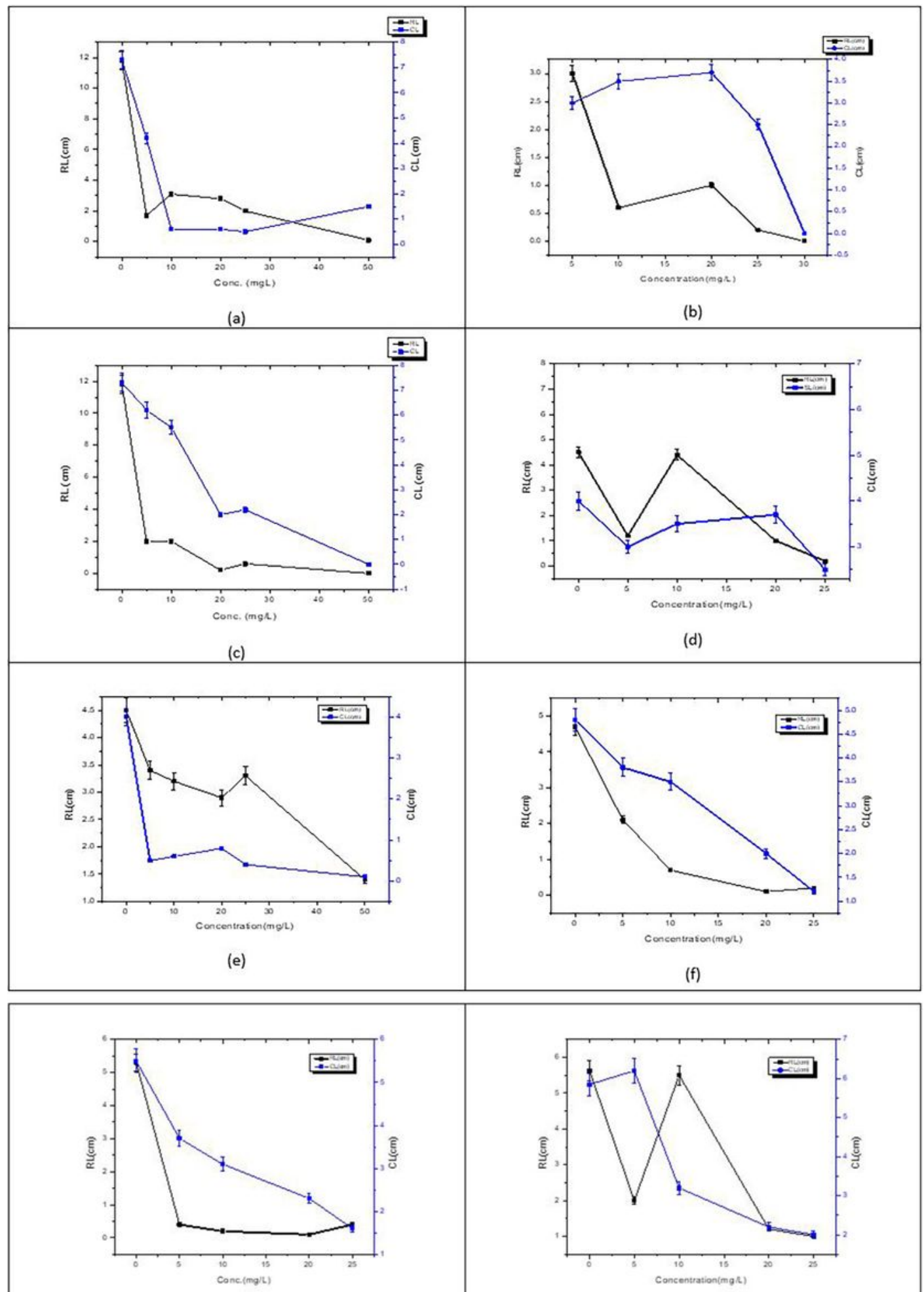

(g)

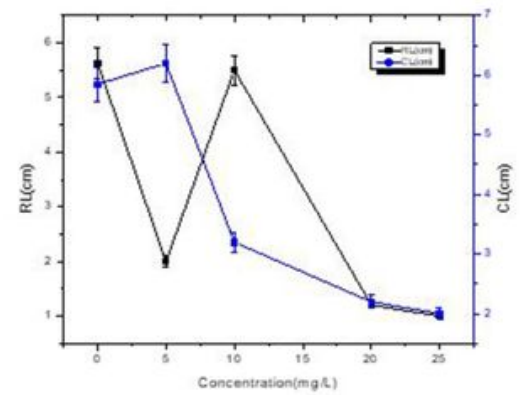

(h)

\section{Figure 3}

Variation of root length and colieopltile length $(\mathrm{cm})$ under different concentration of: (a) As3+ in variety GB1; (b) As3+ in variety MTU 1010; (c) As5+ in variety GB1; (d) As5+ in variety MTU 1010; (e) As3+ in variety 4094; (f) As5+ in variety 4094; (g) As3+ in variety 4786; and (h) As5+ in variety 4786. 


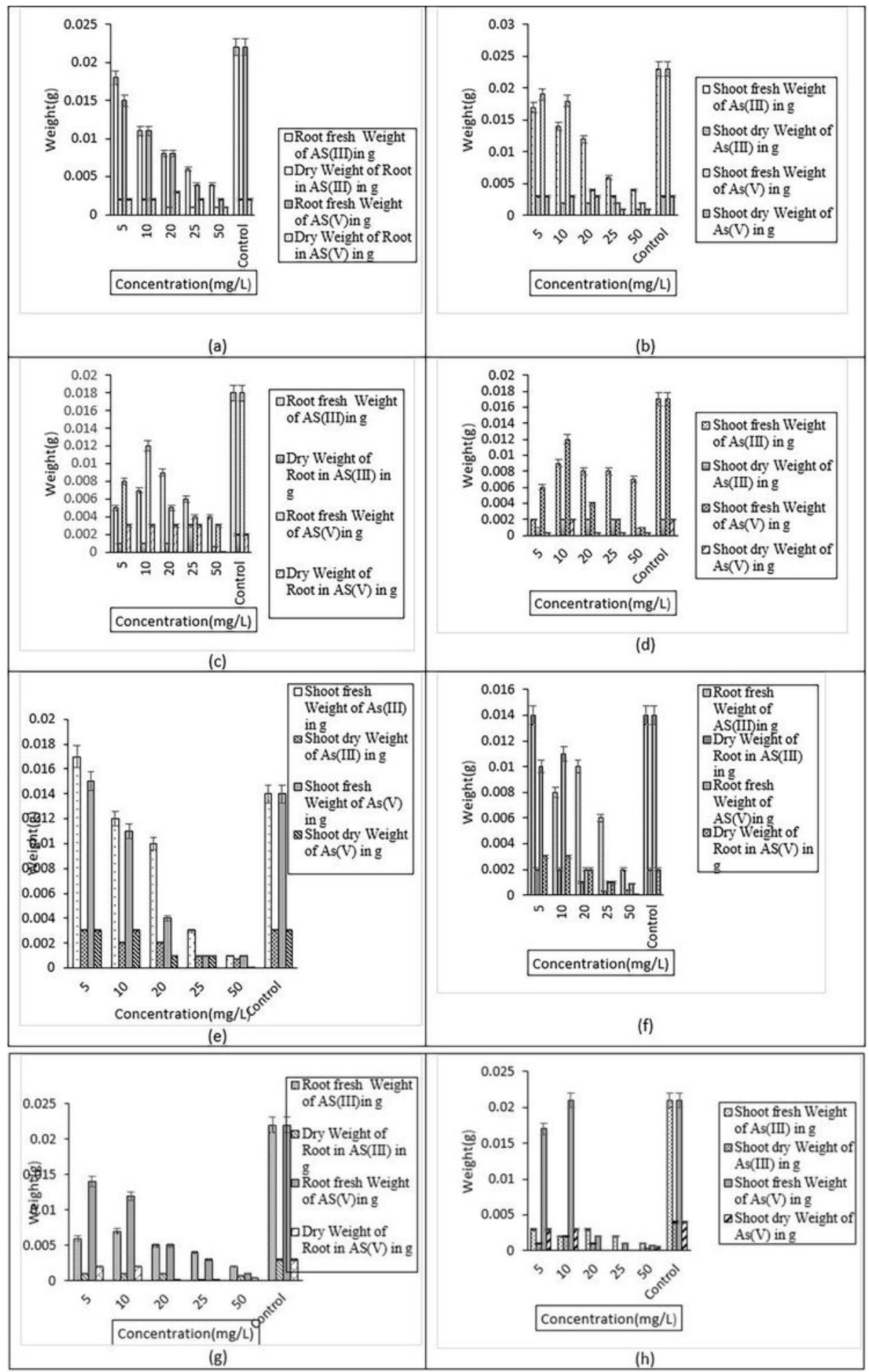

\section{Figure 4}

Fresh and dry biomass of root of four varieties of rice (a)GB-1 under As3+ treatment ; (b)GB-1 under As3+ treatment; (c)IET-4090 under As3+ treatment; (d)IET-4090 under As5+ treatment; (e)MTU-1010 under As3+ treatment; (f) MTU-1010 under As5+ treatment; (g)IET-4786 under As3+ treatment; (h)IET-4786 under As5+ treatment. 


\section{Supplementary Files}

This is a list of supplementary files associated with this preprint. Click to download.

- TableSuppl.docx 